\title{
Towards a Bourdieuian Understanding of the South Asian Language Minorities' Language Acquisition in Hong Kong
}

\author{
Kam Yin Wong \\ Nottingham Trent University, England and Hong Kong
}

\begin{abstract}
Inequalities encountered by South Asian language minorities in education as a result of having inadequate Chinese language skills under the Chinese administration have attracted intensive academia and public concern in Hong Kong. Lacking primary familial and linguistic habitus of Chinese, the language minorities relied heavily or even entirely on the secondary habitus, that is, schools as a mechanism for inculcation. However, the language minorities were located in a space of eliminated opportunities to mingle with their Chinese counterpart in the designated school. Moreover, factors that affected the familial and linguistic habitus inculcation were explored. This study also contributes to the literature of adoption of habitus as a research method to gain a deeper understanding of the familial and linguistic habitus of a small group of South Asian language minorities in Hong Kong.
\end{abstract}

\section{Introduction}

The inadequacy of Chinese language skills of the South Asian language minorities has raised concerns among educators and policymakers in recent years. A survey initiated by the Equal Opportunity Commission revealed that South Asian students accounted for $3.2 \%$ (5452 people) of primary school pupils but dropped to only $1.1 \%$ (1826 people) of senior secondary students and $0.59 \%$ (98 people) of tertiary education students [1]. This underrepresentation in local higher education has caught the attention of the United Nations Human Rights Committee [2] where the situation of the South Asian language minorities has been of paramount concern. The provision of educational support to South Asian students became one of the priorities in the "Initiatives of the 2014 Policy Address" of the Hong Kong Special Administrative Region Government [3]. Whilst there are a number of initiatives to understand and enhance the teaching and learning of Chinese for language-minority students [4] [5] [6], the common denominator of those research studies was a predominant focus on external factors. Although such studies are relevant and useful to understand the many challenges faced by students who are members of language minority, and the origin of their educational challenges, the language minority students were denied a voice and put in a powerless position with little or no control over the elusive problems in Chinese language acquisition. In this case, the major stakeholder, namely the language minorities, seemed to be detached from choices and solutions that might possibly be initiated by them. In this research, the hermeneutic phenomenology stance is adopted to gain a deeper understanding on the life experience of six South Asian language minorities. In attempting to understand the complexities of language practices and strategies employed by the participants to cope with their language needs in Hong Kong, Bourdieu's notions of symbolic power, habitus, capital and field are heavily drawn [7] [8] [9].

\section{Conceptual Framework}

The research employs Bourdieu's habitus as an analysis tool and as a research method [10] [11]. That is, Bourdieu's notion of habitus in relation to capital and field to explain how one's language practice can be shaped or delimited in accordance with the position of the speaker or the participants of this research. In Bourdieu's word, habitus can be summarised as:

"[a] system of durable, transposable dispositions, structured structures predisposed to function as structuring structures, that is, as principles which generate and organize practices and representations that can be objectively adapted to their outcomes without presupposing a conscious aiming at ends or an express mastery of the operations necessary in order to attain them" [12].

In the case of language acquisition, the acquisition of linguistic capital is identical to the formation of habitus. The language one uses is designated by which this determines who has a right to be listened to, to interrupt and to ask questions. In accordance to Bourdieu's practical logic [13], good education for cultural capital means speaking a dominant language that acts as linguistic capital in order to help get a good job which pays well for economic capital, and gains prestige for symbolic capital. The formation of embodied linguistic capital, the Chinese language skills referred to in this study, entails the prolonged exposure to a specialised habitus or immersion environment in which Cantonese should be widely spoken while traditional Chinese characters should be read and written for daily usage. In this regard, the Chinese language acquisition situation encountered 
by the South Asian language minorities is originated to their secondary habitus not tie up with transformation within the domination field. Consequently, it halts their capital exchange and eventually affects their upward social mobility. When the South Asian language minority children fail to cultivate the valued Chinese linguistic habitus through their families, they have to turn to and rely heavily on the education system - schools then become a mechanism for inculcation into the education field.

In this research, the hermeneutic phenomenology stance is adopted to gain a deeper understanding on the life experience of six South Asian language minorities. In attempting to understand the complexities of language practices and strategies employed by the participants to cope with their language needs in Hong Kong, Bourdieu's notions of symbolic power, habitus, capital and field are heavily drawn.

\section{Methods}

Hermeneutic phenomenology is concerned with human experience that may be taken for granted as it is lived with a goal of creating meaning and achieving a sense of understanding [14]. In order to understand the language acquisition and practice of the South Asian language minorities, it is necessary to understand the contexts within which they live, that is, the primary habitus that drives their decisions and practices. In this study, habitus becomes the core method through which the individuals' experiences are understood. The multiplicity of perspectives is one of the features of human experience. In Hong Kong, there is a system of English-medium schools which used to be known as 'designated' schools. These primarily serve language minority students of which a majority tends to be less financially well-off and other than of Caucasian ancestry [15]. To hear the voices of the language minorities about their life histories, I tried to select the most historical designated school as the research setting to locate suitable participants. In this research, personal stories of six language minorities who studied in and graduated from the selected designated school in Hong Kong were collected, followed by the interpretation of the researcher for meanings. Also, 'habitus' was used a research method in terms of a manner of asking questions in the context of the data rather than just as a concept to apply to data analysis. This qualitative research is located within the constructivism paradigm and is based on a philosophy that truth is subjective and knowledge is a constructed reality. Therefore, it is impossible to use the quantitative logic of replication in terms of validity and reliability as a check on credibility [16].

\section{Findings}

The study uncovered the characteristics of the familial and linguistic habitus of the participants, and the factors that affected their familial and linguistic habitus inculcation. The findings are summarised as the following:

\subsection{The characteristics of participants' familial habitus}

Table 1. Six participants' background information

\begin{tabular}{|c|c|c|c|c|}
\hline $\begin{array}{l}\text { Pseud } \\
\text { onyms }\end{array}$ & $\begin{array}{c}\text { Gender/ } \\
\text { Age }\end{array}$ & $\begin{array}{c}\text { Ethnicity } \\
/ \\
\text { Religion }\end{array}$ & $\begin{array}{c}\text { Family } \\
\text { Compositi } \\
\text { on }\end{array}$ & $\begin{array}{c}\text { Generation } \\
\text { in Hong } \\
\text { Kong }\end{array}$ \\
\hline Mar & Female/18 & $\begin{array}{l}\text { Pakistani/ } \\
\text { Muslim }\end{array}$ & $\begin{array}{l}\text { Parents and } \\
\text { one } \\
\text { younger } \\
\text { sister }\end{array}$ & Third \\
\hline Jas & Female/17 & $\begin{array}{l}\text { Indian/ } \\
\text { Sikh }\end{array}$ & $\begin{array}{l}\text { Parents and } \\
\text { three } \\
\text { siblings }\end{array}$ & Third \\
\hline Edi & Male/16 & \multirow[t]{2}{*}{$\begin{array}{l}\text { Indian/ } \\
\text { Hindu }\end{array}$} & \multirow{2}{*}{$\begin{array}{l}\text { Edi was } \\
\text { living with } \\
\text { his father } \\
\text { his parents } \\
\text { and one } \\
\text { sibling, } \\
\text { whom Mr T } \\
\text { is } \\
\text { he father. }\end{array}$} & Second \\
\hline Mr. T & Male/ 46 & & & First \\
\hline Joe & Male/20 & \multirow[t]{2}{*}{$\begin{array}{l}\text { Indian / } \\
\text { Catholic }\end{array}$} & \multirow{2}{*}{$\begin{array}{l}\text { Living with } \\
\text { parents and } \\
\text { being } \\
\text { brothers to } \\
\text { each other }\end{array}$} & First \\
\hline $\mathrm{Ni}$ & Male/18 & & & Second \\
\hline
\end{tabular}

4.1.1. Household size. As indicated in Table 1, Mar, Edi and Mr. T, Joe and Ni's families came from families which were of nuclear household size, consisting of a pair of adults and their children [17]. These participants' households had followed the trend towards smaller family sizes in Hong Kong. This might be attributed to the congested living environment and expensive living standard in Hong Kong so that they made a compromise as regards the reality on their living arrangements.

4.1.2. Gender roles. The traditional role of South Asian women used to be stereotyped as passive and subservient to the husband, performing domestic chores, and bearing children [18]. When I assumed that two girl students and the mothers of the participants would possibly be discouraged to work outside homes, the findings showed completely different stories. Jas's mother was working full-time in a local hotel and being one of the breadwinners to 
support the family with three dependent children. Although Mar's mother was a full-time housewife, Mar revealed that her mother was a capable woman and was able to give views and had made decisions on her education arrangements.

Moreover, Mr. T's wife, who is the mother of Edi, had obtained a master's degree in economics in India. To utilise her academic knowledge, she helped Mr. T run his trading business. Also, she spared time to work as a part-time tutor in a non-governmental organisation helping ethnic minority children in their school work. The familial habitus of the language minorities follows a practical logic through which they assert themselves in the improvisation in the renewed situations. The family structure, size, composition and the gender roles of those participants and their families might imply their familial habitus adaptations and transformations as a result of struggling within active forces.

\subsection{Characteristics of the participants' linguistic habitus}

Table 2. The participants' linguistic habitus and language acquisition

\begin{tabular}{|c|c|c|c|}
\hline \multirow{2}{*}{ Participants } & \multirow{2}{*}{$\begin{array}{c}\text { Languages } \\
\text { inculcated } \\
\text { through } \\
\text { family }\end{array}$} & \multicolumn{2}{|c|}{ A dual mechanism } \\
\hline & & $\begin{array}{l}\text { Languages } \\
\text { inculcated } \\
\text { through } \\
\text { institutes } \\
\text { (Formal } \\
\text { channel) }\end{array}$ & $\begin{array}{c}\text { Languages } \\
\text { inculcated } \\
\text { through peers } \\
\text { (Informal } \\
\text { channel) }\end{array}$ \\
\hline Mar & $\begin{array}{l}\text { Hindko, } \\
\text { Punjabi and } \\
\text { some } \\
\text { Chinese }\end{array}$ & $\begin{array}{l}\text { Chinese, } \\
\text { English and } \\
\text { Urdu }\end{array}$ & $\begin{array}{l}\text { Urdu and } \\
\text { Hindi }\end{array}$ \\
\hline Jas & $\begin{array}{l}\text { Chinese and } \\
\text { Punjabi }\end{array}$ & $\begin{array}{l}\text { Chinese, } \\
\text { English and } \\
\text { Hindi }\end{array}$ & $\begin{array}{l}\text { Urdu and } \\
\text { Hindi }\end{array}$ \\
\hline Edi & Tamil & $\begin{array}{l}\text { Chinese and } \\
\text { English }\end{array}$ & Hindi \\
\hline Mr. T & Tamil & $\begin{array}{l}\text { Tamil, } \\
\text { English, } \\
\text { Hindi and } \\
\text { Turkish }\end{array}$ & $\begin{array}{l}\text { Cantonese, } \\
\text { Hindi, Tamil } \\
\text { and Turkish }\end{array}$ \\
\hline Joe & $\begin{array}{l}\text { English and } \\
\text { Konkani }\end{array}$ & $\begin{array}{l}\text { Chinese, } \\
\text { English, } \\
\text { Hindi and } \\
\text { French }\end{array}$ & $\begin{array}{l}\text { Hindi, } \\
\text { English and } \\
\text { Cantonese }\end{array}$ \\
\hline
\end{tabular}

\begin{tabular}{|c|l|l|l|}
\hline $\mathrm{Ni}$ & $\begin{array}{l}\text { English and } \\
\text { Konkani }\end{array}$ & $\begin{array}{l}\text { Chinese, } \\
\text { English, } \\
\text { Hindi and } \\
\text { French }\end{array}$ & $\begin{array}{l}\text { English and } \\
\text { Cantonese }\end{array}$ \\
\hline
\end{tabular}

4.2.1. Multilingualism. As indicated in Table 2, all six participants were multilingual speakers with various degrees of proficiency. An interesting observation was that none of these South Asian participants was a native Hindi or Urdu speaker. Hong Kong somehow became the place where they were encouraged or made to learn the Hindi or Urdu language though these two languages were hardly used in their daily living. Compared to their local Chinese counterparts just focusing on Chinese and English in schools, the South Asian language minorities very often had to learn at least three languages in designated schools, namely Chinese, English and Hindi/Urdu. English was seldom their mother tongue, while it was the medium of instruction in the designated school; this sheds light on the underachievement of most South Asian students in the local designated schools.

4.2.2. Immersion verse inverse immersion. In addition, languages were in fact acquired through a dual mechanism within the designated school upon analysis. The first mechanism was provided through the official curricula. The majority of the language minority students were grouped into the General Certificate of Secondary Education (GCSE) Chinese Language class so that they were isolated from the Chinese native speakers of the Hong Kong Diploma of Secondary Education (HKDSE) Chinese Language class. In this regard, there were very few, or even no Chinese counterparts studying with the language minority students in the same class. The second mechanism, unofficial but powerful, was established through peer entities enabling the participants to become actively immersed in such language environment. In the absence of a natural Chinese learning environment to mingle with Chinesespeaking students, the language minority students were inversely immersed in a language environment full of Hindi and Urdu speakers. Gradually, the student participants developed their various degrees of proficiency in Urdu and/or Hindi from daily interaction with the other South Asian peers in the class. Habitus is about cumulative exposure to certain social conditions and it instills in individuals an ensemble of 'durable and transposable dispositions' that internalised the necessities of the extant social environment. Through the Bourdieuian lens, immersion through interactions in a selected language speaking environment seems to be a key factor and pedagogy for successful language acquisition at least in conversation level. 


\subsection{Factors affected the linguistic habitus inculcation}

4.3.1. Socioeconomic status. Housing is the most scarce and valuable resource in Hong Kong and therefore provides the potential to be used as a component of socioeconomic status measure. Furthermore, location and housing types are generally recognised as the most important determinant of residential property or housing value and thus able to reflect the socioeconomic status of the households [19]. In the absence of the information about participants' household income provided by the participants, the occupations of the participants' parents (except Mr. T) were employed as one of the major components for socioeconomic classifications in the research. The collected data is summarised in Table 3.

Table 3. The participants' socioeconomic status

\begin{tabular}{|c|c|c|c|}
\hline \multirow[t]{2}{*}{ Participants } & \multirow[t]{2}{*}{$\begin{array}{l}\text { Housing } \\
\text { Type }\end{array}$} & \multicolumn{2}{|c|}{$\begin{array}{c}\text { Parents, } \\
\text { Occupations }\end{array}$} \\
\hline & & Father & Mother \\
\hline Mar & $\begin{array}{l}\text { Public rental } \\
\text { housing }\end{array}$ & $\begin{array}{l}\text { Custom } \\
\text { clothing } \\
\text { shop owner }\end{array}$ & Home- maker \\
\hline Jas & $\begin{array}{l}\text { Public rental } \\
\text { housing }\end{array}$ & $\begin{array}{ll}\text { Law firm } \\
\text { clerk }\end{array}$ & $\begin{array}{l}\text { Hotel } \\
\text { receptionist }\end{array}$ \\
\hline Edi & \multirow{2}{*}{$\begin{array}{l}\text { Privately } \\
\text { owned flat } \\
\text { in } \\
\text { expatriate } \\
\text { residential } \\
\text { area }\end{array}$} & $\begin{array}{l}\text { Trading } \\
\text { company } \\
\text { owner }\end{array}$ & $\begin{array}{l}\text { Part-time } \\
\text { tutor and } \\
\text { homemaker }\end{array}$ \\
\hline Mr. T & & \multicolumn{2}{|c|}{$\begin{array}{l}\text { Trading company owner } \\
\text { (Mr. T's occupation) }\end{array}$} \\
\hline Joe & \multirow{2}{*}{$\begin{array}{l}\text { Average } \\
\text { urban } \\
\text { private } \\
\text { housing }\end{array}$} & \multirow{2}{*}{$\begin{array}{l}\text { Multi- } \\
\text { national } \\
\text { company } \\
\text { manager }\end{array}$} & \multirow[t]{2}{*}{$\begin{array}{l}\text { Bank } \\
\text { administrator }\end{array}$} \\
\hline $\mathrm{Ni}$ & & & \\
\hline
\end{tabular}

As the data indicated, socioeconomic status appeared to have an effect on the motive for the student participants to re/produce Chinese language as their cultural capital. Mar and Jas who lived in public housing flats in neighbourhoods occupied by local Chinese, they tended to have stronger motive to learn Chinese in order to meet their daily needs in the economic and social markets being dominated by Chinese. For Edi who lived in an expatriate residential area with sufficient financial resources, he did not have to speak the local providers' language for what he wanted. Instead, he was free to choose and purchase services from providers who could speak his languages, which were Tamil or English. His economic and cultural capital allowed him to escape from the competition field in Hong Kong and to be free in making choices of his study plan in places where the language of English was used.

4.3.2. Identification and Participation as Hongkongers. Chinese language in terms of Cantonese was much valued by the graduate participants when they had opportunities to interact with their Chinese counterparts after they had left the designated school. Whilst non-Chinese seldom exists in the political system in the post-colonial Hong Kong, Mr. T was invited as a member in the New Arrival Committee under the District Administrative Department where it was dominated by Chinese. Mr. $\mathrm{T}$ made his compromise to attend the meetings conducted in Cantonese. That is, his participation into the new arrival committee, despite the fact that all meetings were conducted in Cantonese, might signify the adaptation and on-going habitus transformation with his new social identification from an immigrant into a 'Hongkonger'.

Meanwhile, Joe admitted that the language of Cantonese functioned as a pathway for him to get more up-to-date information of local politics and thus provided him opportunities to get involved. An interruption eventually took place in the second year of Joe's study in a local university. He was invited by Chinese fellow students to run the departmental committee together. Joe was recognised by the local Chinese as one of their own. The political experiences of Mr. T and Joe illustrated that inclusion and unification lead to the use of Cantonese as their second common spoken language. It provided them as users with linguistic, economic and symbolic capital. They in turn had an interest in supporting the adaptation and transformation of their linguistic habitus that allowed them to exert symbolic domination and mastership in certain extent.

4.3.3. Social Affiliation and Immersion. After graduating from secondary school, Joe and $\mathrm{Ni}$ entered into two different local tertiary institutions where their colleagues were no longer language minorities. The majority were local Chinese who spoke Cantonese. To improve the positions in the tertiary institutions, where Chinese students dominated the informal network, Joe and $\mathrm{Ni}$ maximised their English language ability as their valuable capital, given that English was adopted as the medium of instruction and the required language for assignments. Strategically, Joe and $\mathrm{Ni}$ chose not to act as the South Asian language minority members they had been in the designated school but positioned

themselves as the rare native English speakers. As a result, their cultural capital converted into social capital that they won not only recognition but also friendship from their Chinese peers. On the other hand, the local Chinese students tended to use the ingroup language of Cantonese to communicate with 
Joe and Ni. To transform and qualify Joe and $\mathrm{Ni}$ to be in-group members within the Chinese student communities in the tertiary institutions, these two brothers were enabled by their Chinese peers to develop the new linguistic habitus of Cantonese through their daily encounters. The tertiary institutions of fields formed the interactive and inclusive environments so as to motivate Joe and $\mathrm{Ni}$ to acquire the language of Cantonese to be fit in the identification of Hongkongers. Being recognised and included as ingroup members as Hongkongers by their Chinese peers, Joe and $\mathrm{Ni}$ were more eager to reproduce Cantonese as their cultural capital in order to communicate with their local Chinese counterparts.

\section{Discussion and Conclusion}

The socioeconomic status appears as an issue probably for the first time in a local study that it is associated with the language acquisition and practice of the South Asian language minorities. The research findings show that class-fraction based habitus is a buffer as well as a driving force on the language minorities' Chinese language acquisition which it is particularly distinctive among the student participants. Findings suggest that class fractions, determined by a combination of the varying degrees of social, economic and cultural capital could reflect trends in the participants' consumption correlating with their fit in society. Having a higher socioeconomic status meant that the language minorities could have choices and/or privileges in extensive dining, social and recreational facilities and schoolings where English as well as languages other than Chinese are used to serve expatriates and the prosperous group. On the other hand, habitus is durable because it is formed over a long period of socialisation. For any household where the linguistic habitus of Chinese is absent, institutions become the second chance and most importance arena for the language minorities to inculcate such linguistic habitus to be part of their cultural capital.

Through institutional habitus cultivation, the participants acquired English, Hindi, Urdu and Chinese as their 'second' language in the designated school. Between these four second languages, the linguistic habitus of Chinese was comparatively under-developed than the rest of the other three languages in the history of their designated school. In this case, the Chinese subject cannot simply be taught in designated schools as the first language as for the local Chinese students. A separate curriculum and assessment tool of teaching Chinese as a second language in the context of multilingualism have to be developed to cater the students' unique educational needs.

In addition, the acquisition of Chinese language among the South Asian language minorities presents their reliance on the schools to help them cultivate their linguistic habitus of Chinese. The relational notions of habitus and field were employed to argue that the language minorities' linguistic habitus of Chinese could only be inculcated effectively through exposures and immersion in arenas where the Chinese counterparts were located.

To provide an embracing immersion language environment for the language minorities to practice functional Cantonese in designated schools where the Chinese students are under numbered, buddy programmes between designated schools and nondesignated schools and/or intensive peer-to-peer tutorial class to pair up Chinese Hongkongers with language minorities may be an option. On the other hand, language minorities should be encouraged and empowered to utilise opportunities and take initiatives such as volunteer in various local activities organised by schools, non-governmental organisations and governmental agencies so as to acquire and to enhance their ability in Chinese language in natural environments while public education on racial harmony and integration should be intensified in the community.

\section{References}

[1] Census and Statistics Department, Hong Kong Special Administrative Region, (2012). "Trends in Population and Domestic Households in Hong Kong". Hong Kong Monthly Digest of Statistics, April 2012.

[2] United Nations Human Right Committee, (2013). International Covenant on Civil and Political Rights', April 2013.

[3] Chief Secretary for Administration's Office and relevant Bureau, (2014). Initiative in the policy Address 2014 Support for the Ethnic Minority, January 2014.

[4] Ku, H., Chan, K., \& Sandhu, K. K., (2005). A Research Report on the Education of South Asian Ethnic Minority Groups in Hong Kong. Centre for Social Policy Studies, Department of Applied Social Sciences, The Hong Kong Polytechnic University Hong Kong.

[5] Hau, K., (2008). Tracking the Adaptation and Development of Non-Chinese Speaking Children (NCS) in Mainstream Schools. Chinese University of Hong Kong.

[6] Gao, F., (2011). "Linguistic Capital: Continuity And Change In Educational Language Polices For South Asians In Hong Kong Primary Schools". Current Issues in Language Planning, 12(2), 251-263.

[7] Bourdieu, P., (1991). Language and Symbolic Power. Harvard University Press.

[8] Bourdieu, P., \& Passeron, J., (1990). Reproduction in Education, Society and Culture. Sage.

[9] Bourdieu, P., \& Wacquant, L. J., (1992). An Invitation to Reflexive Sociology. University of Chicago Press. 
[10] Reay, D., (2004). "It's all becoming a habitus': Beyond the Habitual Use of Habitus in Educational Research". British Journal of Sociology of Education, 25(4), 431-444.

[11] Byrom, T., (2008). The Dream of Social Flying': Social Class, Higher Education Choice and the Paradox of Widening Participation. $\mathrm{PhD}$ thesis, University of Nottingham.

[12] [13] Bourdieu, P., (1990). The Logic of Practice. Stanford University Press.

[14] Laverty, S. M., (2008). "Hermeneutic phenomenology and phenomenology: A comparison of historical and methodological considerations". International Journal of Qualitative Methods, 2(3), 21-35.

[15] Evans, S., (2000). "Hong Kong's New English Language Policy in Education". World Englishes, 19(2), 185-204.

[16] Devers, K. J., (1999). "How will We Know "Good" Qualitative Research When We See It? Beginning the Dialogue in Health Services Research". Health Services Research, 34(5 Pt 2), 1153-1188.

[17] Merriam-Webster Online, (2014). Definition of nuclear family. http://www.merriamwebster.com/dictionary/ nuclear\%20family (Access date: 2.3.2014)

[18] Qureshi, K., Charsley, K., \& Shaw, A., (2014). "Marital instability among British Pakistanis: Transnationality, Conjugalities and Islam". Ethnic and Racial Studies, 37(2), 261-279

[19] Coffee, N. T., Lockwood, T., Hugo, G., Paquet, C., Howard, N. J., \& Daniel, M., (2013). "Relative Residential Property Value as a Socio-economic Status Indicator for Health Research". International Journal of Health Geographics, 12(1), 1-10. 